\title{
Stay at (which) home: second homes during and after the COVID-19 pandemic
}

Volkan Zoğal, Antoni Domènech and Gözde Emekli

\begin{abstract}
Purpose - This viewpoint paper aims to provide reflections on the role of second homes in the tourism and housing markets together with future lines of research during and after the first outbreak of the COVID-19 (coronavirus disease 2019) pandemic. The authors aim to review the epistemological evolution of the term "second homes" because of the pandemic, as well as to unfold possible short-, medium- and long-term effects that could place second homes at the center of tourist activity and of the tourist rental market profitability.

Design/methodology/approach - This paper is based on published research studies about the definition of the term "second homes", as well as media sources related to their role during the current situation of the first outbreak of the COVID-19 pandemic.

Findings - In the early stages of the pandemic, second-home owners migrated from crowded cities to low-density areas, being vectors of transmission of the virus. Now, a potential shift in tourist preferences could position second homes at the center of tourist activity as soon as travel restrictions are reduced. This could intensify existing processes of commodification of housing, empowering accommodation platforms and situating the potential for profiteering around the tourist rental market. Parallely, international interests in migrating from crowded cities to low-density areas could also be triggered.

Originality/value - This viewpoint is presented as the confinement measures associated with the new pandemic are being de-escalated in most of the western countries. It is expected that sharing it will provide insights to researchers and practitioners to better plan their research around secondary housing. Its role should be analysed from different perspectives: in the spread of the virus to low-density areas to anticipate mitigation actions in future outbreaks; in the recovery process of (domestic) tourism; in the processes of commodification and financialization of housing in tourist areas; and their impacts on local residents.
\end{abstract}

Keywords Commodification, Tourism geography, COVID-19, P2P platforms, Second homes, Travel behaviour

Paper type Viewpoint

\section{Introduction}

The rapid worldwide spread of SARS-CoV-2 (severe acute respiratory syndrome coronavirus 2) forced the World Health Organization to declare the COVID-19 pandemic on 11 March 2020. Since then, many countries have taken strict measures not only to control the spread of the virus but also to avoid saturation of their health and emergency services. In this regard, both national and international travel restrictions have been imposed together with lockdown measures and shut down of the non-essential economy. In this context of uncertainty, the pandemic might cost the global economy at least \$1th in 2020 according to the UN's trade and development agency (World Economic Forum, 2020), with an important impact on hospitality, tourism and travel sectors, which is faced with a threatening rate of 100 million jobs loss (WTTC, 2020). In fact, tourism mobility has come to a halt globally, reaching ground zero. The latest projections point to a scenario in which, unless a vaccine or effective treatment modality are developed, regular physical distancing measures will continue to be necessary until 2022 (Kissler et al., 2020), as well as travel restrictions and mandatory quarantines will probably also be maintained by many countries.
Volkan Zoğal is based at the Department of Geography, Faculty of Literature, Ege University, Izmir, Turkey. Antoni Domènech is based at the Universitat Rovira i Virgili, Department of Geography, Tarragona, Spain. Gözde Emekli is based at the Department of Geography, Faculty of Literature, Ege University, Izmir, Turkey.

Received 9 June 2020 Revised 20 June 2020 Accepted 7 July 2020

(C) Volkan Zoğal, Antoni Domènech and Gözde Emekli. Published in Journal of Tourism Futures. Published by Emerald Publishing Limited. This article is published under the Creative Commons Attribution (CC BY 4.0) license. Anyone may reproduce, distribute, translate and create derivative works of this article (for both commercial and non-commercial purposes), subject to full attribution to the original publication and authors. The full terms of this license may be seen at http:// creativecommons.org/licences/ by/4.0/legalcode

Research funded by the Spanish Ministry of Science, Innovation and Universities [POLITUR project CSO201782156-R AEI/FEDER, UE], the Department of Research and Universities of the Catalan Government [2017SGR22], the Spanish Ministry of Education and Professional Formation [Doctoral Research Grant FPU15/06947 - Formación de Profesorado Universitario] 
While writing this commentary we are still amid the early stages of the pandemic. Therefore, the uncertainty is gigantic and the long-term effects just keep emerging. Some countries are progressively opening up the lockdown and those more dependent on tourism are aware of the importance of restarting sustainable domestic tourism, minimizing the occurrence of a new outbreak. Some are even considering letting international tourists enter their countries towards the middle or end of the summer season to mitigate the impact on the sector. However, all these decisions might change since they rely upon both the human behaviour and the resistance of the virus itself.

The tourism and hospitality sector must deal with a paradigm change caused not only by the current circumstances induced by the health crisis but also by the potential travel behaviour changes of visitors and tourists associated with their subjectivities and perceptions. Although it is true that there are many perspectives and themes that could be addressed in the field of tourism, we have decided to focus our commentary on the role and meaning of second homes in times of pandemic.

Being able to visit or rent a second home may sound a very first-world issue but with important implications for the economy of tourist areas. Currently, in the new era of the COVID-19 pandemic, the implications go far beyond the economy with an impact on the health of residents who live in tourist areas along the year. In the early period of the pandemic, whether or not there were mobility restrictions introduced, many people decided to move to second homes. Second residences tend to be in less densely populated areas and the origin of the displacement tends to be that of a city where the concerns related with virus infection are large. Therefore, the risk of spreading the virus through the territory is a real threat to the inhabitants of the receiving areas and their health and emergency services.

During the pandemic, second homes have been used as a privileged escape from the big cities where the virus has been spreading stronger, wreaking major havoc in many host tourist areas. However, in the current scenario of opening up the lockdown and letting people travel for tourism purposes, the role of second homes is likely to be shifted because of a potential change in tourist preferences at the time of choosing an accommodation where to stay overnight. Fear of contracting the virus could lead tourists to prefer second homes over certain types of traditional accommodation where physical distancing is more difficult. In this context, the role of sharing accommodation platforms, where second homes are increasingly marketed (Domènech et al., 2019), could be strengthened. Therefore, in the aftermath of the first outbreak of the pandemic, large homeowners of holiday homes owned will potentially occupy a key role in the maximization of profits from the short-term rental market.

After the introduction presented in Section 1, we review the epistemological evolution of the term "second homes" and the shifts induced by the pandemic in Section 2. Then, in Section 3 , we unfold the possible short-, medium- and long-term effects that could place second homes at the centre of tourist activity and of the tourist rental market profitability. Finally, we draw conclusions in Section 4 and pinpoint future research directions in the tourism and hospitality research field.

\section{Shifting meanings of the "second home" concept and the COVID-19 influence}

Second homes also referred to as recreational homes, holiday/vacation homes, summer homes, cottages or weekend homes are considered as an idiosyncratic element of contemporary tourism and mobility (Hall and Müller, 2004). They are generally used for a limited time period and for recreational purposes. However, their use is not exclusively restricted to their owners, familiars and relatives; many tourists with preference for independence opt to rent this type of accommodation over traditional accommodation types, such as hotels or campings (Flognfeldt and Tjørve, 2013).

The origins of second homes date back to ancient societies (Coppock, 1977) and their meaning has been evolving depending on time, regions and cultures. In many countries, 
people purchase second homes to reach geographical and cultural attractions that are not available in their primary residential areas. The driving factors that push people to buy a second home are of diverse nature, such as wanting to be in a natural environment, looking for an authentic lifestyle in rural areas, or wanting to rest by the sea/lake and walk along promenades. After the industrial revolution, mass tourism came to the forefront with the change of tourism habits and tourism paradigms. People have begun to devote more time to travel and with the increase in private car ownership, the number of second homes has increased in the close circles of the living places and, especially, on the coasts. Other driving factors can also be strongly related to family traditions and culture in some territories. In the Nordic region, for example, many people continue to use the second homes inherited from their ancestors as an expression of their identity (Hall, 2014). Likewise, second homes in high altitude areas are still used by many people as a part of the culture to escape the heat weather in the summer months in countries such as Turkey. With globalization and blurred borders between countries, second homes have also progressively gained an international dimension (Lipkina, 2013; Müller, 2002). The demand for second homes has increased internationally either for holiday purposes or as a part of lifestyle and retirement migration. This has led to tourism urbanization and speculation processes that have consolidated areas with a predominance of second homes. In fact, in the context of ever-growing tourism mobilities, the investment in second homes has lower risk compared to hotels because of their lower depreciation values and lower management and maintenance costs. Therefore, second homes are sometimes, and increasingly, seen as an investment tool that is offered to tourists for rent via short-term rental platforms rather than used by its owners (Dias et al., 2015). The emergence of the so-called "sharing accommodation platforms" of Airbnb or HomeAway has been an opportunity for second home owners to benefit from their homes and extract profits from the tourist market (Domènech et al., 2019). However, the number of homes offered on these platforms in the hands of large owners is increasing substantially, indicating a professionalization of these platforms (Gutiérrez and Domènech, 2020). In other words, large investors purchase housing packages to offer them as short-term rentals, which demonstrates the central role of these platforms in the intensification of the commodification of housing.

COVID-19 pandemic is the most recent social issue affecting the meaning of the "second home" concept. In the early stages of the COVID-19 pandemic owners of second homes saw them as an escape from urban areas where the spread of the virus was advancing faster. In some countries, the mobility to second homes was carried out before and even after travel restrictions were imposed by governments. Some of the reasons for these were associated with the concern to avoid getting infected, the desire to be isolated or to stay away from crowds and, obviously, to enjoy the commodities of the host area while (maybe) doing teleworking. Hence, second home use has been expanded from recreational and tourism purposes to "shelter from pandemics" and "place for privileged teleworking". In the process of doing this loophole mobility towards coastal, rural and mountain areas, the measures related with the spread of the virus were automatically put into effect. The main concerns about this mobility were associated with the fear of bringing the virus to less-populated areas (some of which have an important percentage of elder inhabitants) and the extra pressure that the spread of the virus could exert by out-of-towners on the local healthcare systems. This situation might have been better controlled in island territories than in inland areas. Such was the case of Mallorca, where hundreds of owners with second homes and business in the island were not allowed to return because of the declaration of the state of emergency in Spain (Badcock, 2020). On the contrary, many citizens decided to breach the travel restrictions and move to second homes in the peninsula, despite knowing that they would be fined $€ 1,500$ (Idealista, 2020). Likewise, in the county of Cumbria, at the North West of England, many villages with the presence of second homes received an important influx of citizens from other parts of the country, but particularly from London (BBC, 2020). Right after the arrival of urban citizens to places such as Cornwall, the Lake District, and Norfolk the number of infections 
soared above the average. To make it worse, this occurred in a paradoxical context in which those owners who have their second home regulated as holiday let (140 days/year) could have access to the government support package for businesses, which would imply £10,000 available to every second-home owner (Duggan, 2020).

On April 2, when the number of cases was announced on a provincial basis in Turkey, there was intense human mobility from city centres where the number of cases was highest such as İstanbul, Ankara and Izmir to the resort areas with a high number of second homes (mostly summer houses) on the Mediterranean coast (Sputnik, 2020). People usually visit these areas for vacation but this time it was with the intention of escaping the virus. Two days later on April 4, the government announced restrictions for entry and exit for 31 risky provinces to curb the spread of the coronavirus pandemic and extended these travel restrictions for 15 days later again (Ministry of Interior - Republic of Turkey, 2020). As a result, local administrators had to warn people with such warnings as "do not come" and "stay at home" but many people responded to this call by staying in an owned or rented second home. This fact raises debates about the second home concept itself and about the issue, taking it from second home to "permanent home", at least in times of pandemics.

\section{Second homes after the first COVID-19 wave}

The role of the second homes in the "new normality" is expected to have implications and effects on the tourism and housing markets. The eruption of coronavirus has emerged multiple trends that could be long-lasting. Hence, this section is articulated around three dynamics that lie ahead and that will certainly be topics of interest to researchers and public administrations in the coming months and years.

\subsection{Potential shift in travel behaviour and tourist preferences}

The future of tourism and traditional accommodation is still uncertain although some countries have already scheduled to open up their borders and remove or diminish travel restrictions. In this new context, significant changes are expected to happen both in the tourism policies of countries and in the preferences of tourists. Hall et al. (2020, p. 15) stated that "Some destinations will undoubtedly reconsider the nature of their tourism industry and focus more on local and more sustainable forms of tourism". Similarly, Lapointe (2020) emphasized that the tourism sectors would have to show more orientation to host communities in many countries because of COVID-19. In this regard, in the normalization process, many countries are appealing to domestic mobility as a short-term solution to mitigate the effects of the pandemic on the hospitality and tourism sector. Together with this national tourism, there might be a travel behaviour shift because of fear of virus outbreak and ongoing uncertainty about how traditional accommodation (i.e. hotels) restore customer trust. The desire for privacy and independence can tip the balance in favour of second homes and tourist apartments over traditional accommodation. However, not only nonmobile second homes but also mobile and semi-mobile second homes such as caravans (Herranz, 2020), boats and tents are likely to face an increase in demand. Those are seen as the address of freedom, safety space and escape to nature.

\subsection{Commodification of housing: peer-to-peer platforms, manager channels and speculation in rental housing}

After the crash of the real estate and financial crisis of 2008, an intensive process of commodification and financialization of housing (Aalbers, 2016; Madden and Marcuse, 2016) carried out by real estate companies and investors took place around the optimal flexibility that the tourist rental market offered them to maximise profits. In this process, the so-called "peer-to-peer (p2p) platforms" facilitating the offer and rental of short-term rentals (i.e. Airbnb or HomeAway) were situated at the core of the business (Cócola-Gant, 2020). In 
fact, Airbnb became the company managing the largest volume of tourist accommodation in the world (Jefferson-Jones, 2015). Along with these platforms, the number of technological firms managing the offer of housing units on multiple digital channels, also known as "channel managers", has increased globally. These enterprises not only offer the tourist apartments on multiple short-term rental platforms but also on "originally" long-term rental platforms (i.e. Idealista or Rightmove) indicating that the rental is not for a long period of time (i.e. for the period of the university course). Hence, housing has lost its social use and is just seen as a financial asset (Byrne, 2020) providing flexibility and a high capacity to adapt to the market circumstances.

Considering the intrinsic flexibility of tourist apartments, it seems that in the aftermath of the first outbreak of the pandemic, these dynamics will be maintained and might even be accentuated in some highly touristic places. The emergence of a new demand or, at least, the shift of demand towards tourist apartments and second homes will extend the already existing opportunities for profiteering from the tourist rental market. In the short-run of the pandemic short-term rentals have become a suitable option for travellers seeking mid-term stays and willing to flee from urban destinations to low-density areas. In this line, a report prepared by the consultancy AirDNA portrays that half of the bookings on Airbnb in 2020 have been extended to an average of more than two weeks (DuBois, 2020). It showcases that tourist rentals are unlikely to be reconverted to long-term rentals for locals, therefore intensifying such processes as increase of long-term rental housing prices (because of its shortage), home dispossession, displacements and the gentrification of urban centres (García-Lamarca and Kaika, 2016). These processes will not only take place in touristified areas but also in working-class neighbourhoods near tourist sites and with high potential for generating new profits (Gutiérrez and Domènech, 2020).

\subsection{Migration to low-density areas: a first world "issue"}

Migration to second home areas is a subject that has been focused on by academics for a long time, with the concepts of retirement and lifestyle migration. Pandemic will also change the priorities and preferences of both second home owners and people with a privileged economic situation with the capacity to purchase a second home.

In the first place, regarding those owners of second homes, travel restrictions might have caused them to reconsider the fact of having a first residence in large cities, where the risk of infection is higher while the possibilities of being isolated are limited. In this regard, there might be an exchange between the first and second homes. In fact, some coastal destinations with an important volume of second homes have experienced an increase in the number of owners asking to be enumerated to the municipal register (El Punt Avui, 2020). Thereby, they would be able to overcome travel restrictions during the ongoing (and potentially future) lockdown periods and settle in their secondary (now permanent) home. This, as commented in Section 2, opens up new discussions about the second home concept itself and its meaning.

In the second place, seeking a better life will come into prominence again, especially for people with a privileged economic situation residing in crowded cities. The pandemic has induced the fear of contagion and, for the first time in a long time, low-density areas are beginning to be valued as safe living spaces not just as leisure or tourist places. In this context, wealthy urban citizens may be tempted to purchase a second home in areas of lower density, such as coastal destinations or authentic and protected rural areas. In this process of rethinking their future, the possibility of remote working is another drive that might push people to lose attachment to cities and plan to buy a new home or go back to the region their family had lived in for generations. The emergence of this demand can fuel speculation around housing, and especially with regard to the sale and rental prices of second homes in the resort and rural areas with high potential for profiteering. Examples of this demand are already being seen in some destinations. In Italy, for example, requests and online searches for country homes increased by $20 \%$ between February and April (Speak, 2020). Similarly, the largest 
property website in the UK revealed that the coronavirus has increased the number of the British citizens looking for remote locations to buy a home. Luxurious and low-density places such as Inverness in the Scottish Highlands or the Shetland Islands experienced a, respectively, 167\% and 131\% year-on-year increase in searches in April (Rightmove, 2020). Also in Spain, with the stretching of international restrictions, an increase is expected in the international demand for holiday homes or retirement properties in tourist regions such as the Costa de Sol or Costa Blanca (Trelinski, 2020).

\section{Conclusions}

This viewpoint paper has centred around the role of second homes in times of COVID-19 and in the aftermath of the first outbreak of the pandemic. Concretely, it has reviewed the evolution of the meaning of second homes because of the eruption of the virus. Moreover, it has described the main emerging challenges, potential problems and opportunities for areas with a high presence of this type of housing. Overall, the paper allows us to foresee a scenario in which second homes might not only be at the center of tourist activity in the "post-pandemic" period but also occupy a key role in the housing market. Nevertheless, all the trends and dynamics pointed out have to be further explored and empirical evidence is needed in the months ahead. Therefore, this viewpoint paper draws four main lines of present and future research that must be faced with an interdisciplinary vision.

First, the potential shift in travel behaviour and tourist preferences after lifting travel restrictions have to be analysed and dimensioned. It will likely result in a displacement of demand to second homes and apartments, but the size of this phenomenon, its reasons and its consequences are important factors to be assessed. Some potential research questions involve the following: "Will second homes become the main preference for accommodation and why? "Is there a social logic behind this potential shift?" "How do traditional accommodation adapt to the new situation?"

Second, as linked with the previous, the potential for profiteering by real estate companies will probably increase substantially, in the same way that housing management platforms (channel managers or p2p platforms) will continue to occupy a key role in the process of commodification and financialization of housing from the tourist rental market (Aalbers, 2016; Byrne, 2020; Madden and Marcuse, 2016). This opens up interesting research questions such as: "How will the tourist rental market evolve?" "What are going to be the effects on the prices of long-term rental housing?" "What are going to be the impacts on different social groups, regions and neighbourhoods?" As in all crises, the most vulnerable social groups tend to be the most affected. The effects of the pandemic on the housing market can, therefore, contribute to exacerbating the negative externalities caused by the proliferation and consolidation of tourist apartments and the business around second homes. Furthermore, the consequences in the short and mid-term for the so-called "gig workers" of the p2p accommodation sector should be analysed.

Third, there might be changes in the preferences of private second home owners. Some of them, in the short-run, considered converting their second homes into first residences in order to escape from urban areas where the risk of contagion was higher. In this regard, not only research focusing on this urban to low-density areas' migration is needed, but also it is important to detect the temporality of these decisions: "Will second homes be converted into "permanent homes" in the process of normalization?" "What are the main reasons and socioeconomic drivers of these decisions?" "Is there any specific spatial logic?" "Will this 'permanization of second homes' be long-lasting or just until no effective treatment or vaccine is found?"

Fourth and last, the pandemic has made many people who live in crowded cities rethink their lifestyles. Spacious and comfortable homes to spend time, relax and work are now more valued not only as getaways from the risk of contagion but also as places to live in. For this reason, many people, with a certain wealthy situation, will re-evaluate their home situations. In 
this sense, the analysis of the housing market and the evolution of people's preferences should be analysed, as well as the implications it might have for the future of host areas.

\section{References}

Aalbers, M.B. (Ed.) (2016), The Financialization of Housing: A Political Economy Approach, Routledge, London.

Badcock, J. (2020), "German tourists demand access to their Spanish island holiday villas", available at: www.telegraph.co.uk/news/2020/05/02/german-tourists-demand-access-spanishisland-holiday-villas/ (accessed June 19).

BBC (2020), "Coronavirus: second-home owners 'claiming £10,000 in virus support", available at: www. bbc.com/news/uk-england-cumbria-52420392 (accessed June 19).

Byrne, M. (2020), "Generating rent and the financialization of housing: a comparative exploration of the growth of the private rental sector in Ireland, the UK and Spain", Housing Studies, Vol. 35 No. 4, pp. 743-765, doi: 10.1080/02673037.2019.1632813.

Coppock, J.T. (Ed.) (1977), Second Homes: Curse or Blessing?, Pergamon, Oxford.

Cócola-Gant, A. (2020), "Apartamentos turísticos, covid-19 y capitalismo de plataformas (tourist apartments, covid-19 and platform capitalism)", available at: www.albasud.org/noticia/es/1220/ apartamentos-tur-sticos-covid-19-y-capitalismo-de-plataformas (accessed May 26).

Dias, J.A., Correia, A. and López, F.J.M. (2015), "The meaning of rental second homes and places: the owners' perspectives", Tourism Geographies, Vol. 17 No. 2, pp. 244-261, doi: 10.1080/ 14616688.2014.959992.

Domènech, A., Larpin, B., Schegg, R. and Scaglione, M. (2019), "Disentangling the geographical logic of Airbnb in Switzerland", Erdkunde, Vol. 73 No. 4, pp. 245-258, doi: 10.3112/erdkunde.2019.04.01.

DuBois, D. (2020), "How mid-term stays may rescue short-term rentals", available at: www.airdna.co/ blog/how-mid-term-stays-may-rescue-short-term-rentals (accessed May 26).

Duggan, C. (2020), "Coronavirus: second-home owners 'use loophole' to claim grants", available at: www.bbc.com/news/uk-wales-52316003 (accessed May 30).

El Punt Avui (2020), "L'empadronament es dispara en municipis de costa i de la Cerdanya durant els mesos de confinament (census registrations are triggered in coastal and Cerdanya municipalities during the months of confinement)", available at: www.elpuntavui.cat/societat/article/5-societat/ 1801983-I-empadronament-es-dispara-en-municipis-de-costa-i-de-la-cerdanya-durant-els-mesosde-confinament.html (accessed June 18).

Flognfeldt, T. and Tjørve, E. (2013), "The shift from hotels and lodges to second-home villages in mountain-resort accommodation", Scandinavian Journal of Hospitality and Tourism, Vol. 13 No. 4, pp. 332-352, doi: 10.1080/15022250.2013.862440.

García-Lamarca, M. and Kaika, M. (2016), "'Mortgaged lives': the biopolitics of debt and housing financialisation", Transactions of the Institute of British Geographers, Vol. 41 No. 3, pp. 313-327, doi: 10.1111/tran. 12126.

Gutiérrez, A. and Domènech, A. (2020), "Understanding the spatiality of short-term rentals in Spain: Airbnb and the intensification of the commodification of housing", Geografisk Tidsskrift-Danish Journal of Geography, doi: 10.1080/00167223.2020.1769492.

Hall, C.M. (2014), "Second home tourism: an international review", Tourism Review International, Vol. 18 No. 3, pp. 115-135, doi: 10.3727/154427214X14101901317039.

Hall, C.M. and Müller, D.K. (Eds) (2004), "Introduction: second homes, curse or blessing? Revisited", Tourism, Mobility and Second Homes: Between Elite Landscape and Common Ground, Channel View, Clevedon, pp. 3-14

Hall, C.M., Scott, D. and Gössling, S. (2020), "Pandemics, transformations and tourism: be careful what you wish for", Tourism Geographies, Vol. 22 No. 3, pp. 577-598, doi: 10.1080/ 14616688.2020.1759131.

Herranz, C. (2020), Es dispara el lloguer d'autocaravanes: no en quedarà cap de lliure per passar-hi l'estiu (The rental of caravans is on the rise: none will be left free to spend the summer there), available at: 
www.ccma.cat/324/es-dispara-el-lloguer-dautocaravanes-no-en-quedara-cap-de-lliure-per-passar-hilestiu/noticia/3020155/ (accessed June 18).

Idealista (2020), "1,500 Euro fine for those breaking lockdown rules and travelling to their second homes in Spain", available at: www.idealista.com/en/news/lifestyle-spain/2020/04/22/7490-1500-euro-finethose-breaking-lockdown-rules-and-travelling (accessed 19 June).

Jefferson-Jones, J. (2015), "Airbnb and the housing segment of the modern sharing economy: are short-term rental restrictions an unconstitutional taking?", Hastings Constitutional Law Quarterly, Vol. 42 No. 3, pp. 557-575, available at: https://repository.uchastings.edu/hastings_constitutional_law_quaterly/vol42/iss3/3

Kissler, S.M., Tedijanto, C., Goldstein, E., Grad, Y. and Lipsitch, M. (2020), "Projecting the transmission dynamics of SARS-CoV-2 through the pandemic period", Science, Vol. 368 No. 6493, pp. 860-868, doi: 10.1126/science.abb5793.

Lapointe, D. (2020), "Reconnecting tourism after COVID-19: the paradox of alterity in tourism areas", Tourism Geographies, Vol. 22 No. 23, pp. 633-338, doi: 10.1080/14616688.2020.1762115.

Lipkina, O. (2013), "Motives for Russian second home ownership in Finland", Scandinavian Journal of Hospitality and Tourism, Vol. 13 No. 4, pp. 299-316, doi: 10.1080/15022250.2013.863039.

Madden, D. and Marcuse, P. (2016), Defense of Housing: The Politics of Crisis, Verso Books, New York, NY.

Ministry of Interior - Republic of Turkey (2020), "Ş ehir giriş/çıkış tedbirleri ve yaş sınırlaması (city entry/exit measures and age restriction)", available at: www.icisleri.gov.tr/sehir-giriscikis-tebirleri-ve-yassinirlamasi (accessed June 18).

Müller, D.K. (2002), "Reinventing the countryside: German second-home owners in Southern Sweden", Current Issues in Tourism, Vol. 5 No. 5, pp. 426-446, doi: 10.1080/13683500208667933.

Rightmove (2020), "More people want to live in remote locations (\& Captain Tom's village)", available at: www.rightmove.co.uk/news/articles/property-news/more-people-want-to-live-in-remote-locations-captaintoms-village (accessed 31 May).

Speak, C. (2020), "Demand surges for homes in the Italian countryside during lockdown", available at: www.thelocal.it/20200507/demand-surges-for-homes-in-the-italian-countryside-during-lockdown (accessed 31 May).

Sputnik (2020), "Büyükşehirlerden bodrum ve marmaris'e yığılma yaşandı (migration from metropolitan cities to bodrum and marmaris)", available at: https://tr.sputniknews.com/turkiye/202004041041756255buyuksehirlerden-bodrum-ve-marmarise-yigilma-yasandi/ (accessed June 18).

Trelinski, A. (2020), "New mortgages in Spain's property market fall under pandemic lockdown strain as holiday home buyers face summer price rises", available at: www.euroweeklynews.com/2020/05/27/newmortgages-in-spains-property-market-fall-under-pandemic-lockdown-strain-as-holiday-home-buyers-facesummer-price-rises/ (accessed in 31 May).

World Economic Forum (2020), "This is how much the coronavirus will cost the world's economy, according to the UN", available at: www.weforum.org/agenda/2020/03/coronavirus-covid-19-costeconomy-2020-un-trade-economics-pandemic/ (accessed May 31).

WTTC (2020), "WTTC now estimates over 100 million jobs losses in the travel \& tourism sector", available at: https://wttc.org/News-Article/WTTC-now-estimates-over-100-million-jobs-losses-in-the-Travel-\&Tourism-sector-and-alerts-G20-countries-to-the-scale-of-the-crisis (accessed May 31).

\section{About the authors}

Volkan Zoğal is PhD candidate in the Department of Geography at Ege University. He received his master's degree in 2016 and continues his PhD dissertation at Ege University Graduate School of Social Sciences, Human and Economic Geography Program. His PhD dissertation is about geographical dimensions of short-term rentals through Airbnb and its possible effects on the coastal second home areas of Turkey. His main research interests are: tourism geography, second home tourism, sharing economy, peer-to-peer accommodation and Airbnb. He is currently working at the Ege University Geography Department as a research assistant. Volkan Zoğal is the corresponding author and can be contacted at: volkan.zogal@ege.edu.tr 
Antoni Domènech is PhD candidate in the Department of Geography at Universitat Rovira i Virgili. He holds a bachelor's degree in Geography and Territorial Planning (2015) and master's degree in Regional Analysis and Management (2016). His research deals with the use of new technologies to analyse the mobility of people -both visitors and residents- in tourism destinations. He is author of several papers and publications on mobility and public transport and other urban studies.

Prof Dr Gözde Emekli is Professor in the Department of Geography at Ege University since 2016. She is author of several papers on cultural geography, second home tourism, creative tourism, cultural heritage, rural studies and other urban cultural tourism studies. She is also reviewers for several journals including International Journal of Geography and Geography Education, Aegean Geographical Journal, Turkish Journal of Geographical Sciences, Turkish Geographical Review. Currently, she gives lectures on Tourism Geography, Urbanization in Turkey, Research Methods in Human Geography, European Union and Alternative Tourism Opportunities in Turkey for undergraduate and postgraduate students.

For instructions on how to order reprints of this article, please visit our website: www.emeraldgrouppublishing.com/licensing/reprints.htm

Or contact us for further details: permissions@emeraldinsight.com 